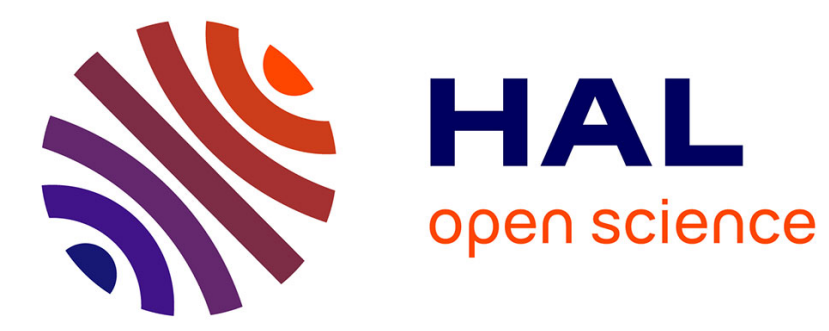

\title{
The effects of several common anthropogenic contaminants on proliferation of the parasitic oyster pathogen
}

David Bushek, Megan Heidenreich, Dwayne Porter

\section{- To cite this version:}

David Bushek, Megan Heidenreich, Dwayne Porter. The effects of several common anthropogenic contaminants on proliferation of the parasitic oyster pathogen. Marine Environmental Research, 2007, 64 (4), pp.535. 10.1016/j.marenvres.2007.03.004 . hal-00562975

\section{HAL Id: hal-00562975 \\ https://hal.science/hal-00562975}

Submitted on 4 Feb 2011

HAL is a multi-disciplinary open access archive for the deposit and dissemination of scientific research documents, whether they are published or not. The documents may come from teaching and research institutions in France or abroad, or from public or private research centers.
L'archive ouverte pluridisciplinaire HAL, est destinée au dépôt et à la diffusion de documents scientifiques de niveau recherche, publiés ou non, émanant des établissements d'enseignement et de recherche français ou étrangers, des laboratoires publics ou privés. 


\section{Accepted Manuscript}

The effects of several common anthropogenic contaminants on proliferation of the parasitic oyster pathogen Perkinsus marinus

David Bushek, Megan Heidenreich, Dwayne Porter

PII:

S0141-1136(07)00045-1

DOI:

10.1016/j.marenvres.2007.03.004

Reference:

MERE 3112

To appear in:

Marine Environmental Research

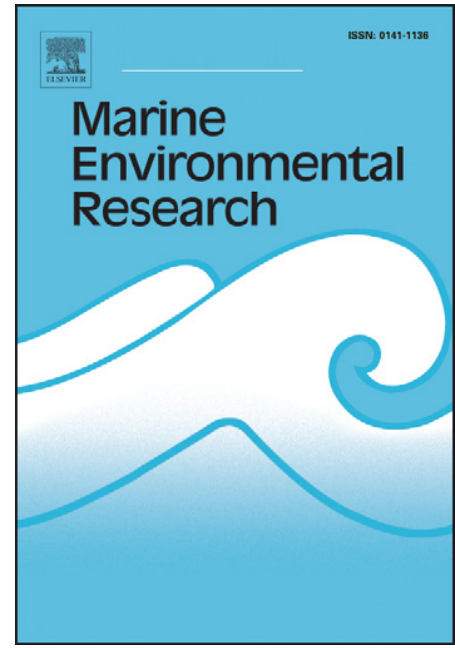

Received Date: $\quad 8$ October 2006

Revised Date: 6 February 2007

Accepted Date: $\quad 11$ March 2007

Please cite this article as: Bushek, D., Heidenreich, M., Porter, D., The effects of several common anthropogenic contaminants on proliferation of the parasitic oyster pathogen Perkinsus marinus, Marine Environmental Research (2007), doi: 10.1016/j.marenvres.2007.03.004

This is a PDF file of an unedited manuscript that has been accepted for publication. As a service to our customers we are providing this early version of the manuscript. The manuscript will undergo copyediting, typesetting, and review of the resulting proof before it is published in its final form. Please note that during the production process errors may be discovered which could affect the content, and all legal disclaimers that apply to the journal pertain. 


\section{Short Communication}

Title: The effects of several common anthropogenic contaminants on proliferation of the parasitic oyster pathogen Perkinsus marinus.

Authors: David Bushek ${ }^{1 *}$, Megan Heidenreich ${ }^{2}$, and Dwayne Porter ${ }^{3}$

${ }^{1}$ Haskins Shellfish Research Laboratory, Rutgers, The State University of New Jersey, 6959 Miller Avenue, Port Norris, NJ 08349

$10{ }^{2}$ Ocean Process Analysis Laboratory, University of New Hampshire, Durham, NH 03824

${ }^{3}$ Arnold School of Public Health and the Baruch Institute for Marine and Coastal Sciences, University of South Carolina, Columbia, SC 29208

*Corresponding Author: David Bushek, Haskin Shellfish Research Laboratory, 6959 Miller

15 Avenue, Port Norris, NJ 08349. Phone: (856) 785-0074, Fax: (856) 785-1544, e-mail: bushek@hsrl.rutgers.edu
Abstract:
Estuarine contaminants have varying effects on estuarine inhabitants and host-parasite
20 interactions. Some field collected contaminant mixtures have been shown to increase oyster susceptibility to parasitism by Perkinsus marinus, but little is known about contaminant effects on the parasite itself. This study examined the effects of ammonium, nitrate, phosphate, fluoranthene, phenanthrene and a common herbicide mixture (Weed-B-Gone ${ }^{\circledR}$ ) on in vitro 
proliferation of $P$. marinus. Only the herbicide had a significant effect, but not at or below the

25 manufacuture's recommended application rate $\left(7.81 \mu 1 \mathrm{~mL}^{-1}\right)$. The herbicide's active ingredients (3.1\% 2,4-dichlorophenoxyacetic acid, $10.6 \%$ mecoprop and $1.3 \%$ dicamba) mimic growth hormones of broadleaf plants; over stimulation of growth results in death. The mode of action of these compounds on $P$. marinus warrants further investigation which may provide insight towards the identification of biocides to control $P$. marinus.

30

Key words: shellfish, disease, dermo, protozoan, estuary, pollution

During the past century, populations of the Eastern oyster Crassostrea virginica have declined dramatically in mid-Atlantic bays along the coast of North America (e.g., Rothschild et

35 al. 1994). Concurrently, extensive anthropogenic alterations have changed many facets of the estuaries where the oysters once thrived. One noteworthy alteration has been the increase in chemical contaminants, several of which have been shown to negatively impact oysters and increase their susceptibility to dermo disease (Chu and Hale 1994, Anderson et al. 1996, 1998, Fisher et al. 1999, Chu et al. 2002). Several parasitic pathogens plague the eastern oyster (Ford and Tripp 1996), but the protozoan parasite Perkinsus marinus, which causes dermo disease, has been a primary source of oyster mortality for decades (Burreson and Calvo 1996) and is a major impediment to the recovery of eastern oyster populations (Brown et al. 2005). Few studies, however, have examined the impact that estuarine contaminants have on P. marinus. Lafferty (1997) described how the effects of anthropogenic inputs could be positive,

45 negative, or neutral with respect to parasites and disease. In general, pesticides, metals and PAHs have negative impacts on most biota, although some microbes can use these compounds to 
their advantage (Heitkamp et al. 1988). If $P$. marinus can utilize a contaminant that is detrimental to oysters, the negative impact of that particular contaminant on the disease status of the oysters may be exacerbated. On the other hand, some contaminants may harm the parasite 50 without affecting the host, resulting in a net benefit to the host. Indeed, herbicides, pesticides and antibiotics are explicitly designed and applied for just this purpose. Once such compounds move beyond their target populations, in runoff flowing into estuaries for example, they become contaminants. The interacting forces of different contaminants may confound the interpretation of the impact that a particular contaminant or class of contaminants has on any particular

55 organism. The present study examined the effect of six common anthropogenic chemical contaminants (Table 1) on in vitro proliferation of $P$. marinus.

Parasites. Perkinsus marinus strains (ATCC 50509, 50775 and 50763) that represent three distinct genotypes (Reece et al. 2001) were grown in ATCC 1886 medium (www.atcc.org) with minor modifications described in Bushek et al. (2000). Genetically distinct strains derived

60 from different geographic locales were used as replicates to ensure that results were not specific to the sensitivity of any particular genotype. Parasites were harvested for chemical challenge experiments from cultures undergoing log-phase growth. Cell density was determined by repeated $(n=3)$ hemocytometer counts (La Peyre and Chu 1994) and 1-mL aliquots containing equivalent numbers of parasites used to seed wells in a 24-well culture plate. Seeding densities

65 varied among chemicals from 0.5 to $2.0 \times 10^{6}$ parasites $\mathrm{mL}^{-1}$, but not among treatments within chemicals. These seeding densities yield rapidly proliferating populations within a few days (Gauthier and Vasta 1995).

Chemicals and Treatments. Table 1 identifies the chemicals and concentrations tested. Reagents were dissolved in deionized water or acetone, depending on solubility, then in fresh 
70 culture medium to create $10 \mathrm{x}$ working stocks relative to test concentrations. Final dilutions were performed with culture medium that contained $P$. marinus in log-phase growth. Ammonium chloride, sodium nitrate, and sodium phosphate were used as sources of ammonium, nitrate and phosphate with test concentrations selected to include and exceed the range of these chemicals observed in estuarine waters at the North Inlet-Winyah Bay National Estuarine Research

75 Reserve, South Carolina, US (data available at http://cdmo.baruch.sc.edu/). The herbicide Weed-B-Gon®, which contained a mixture of 2,4-dichlorophenoxyacetic acid (= 2,4-D, CAS\# 2008-39-1); 2-(2-Methyl-4-chlorophenoxy)propionic acid, dimethylamine salt (= mecoprop, CAS\# 32351-70-5); and 2,5-Dichloro-6-methoxybenzoic acid (= dicamba, CAS\# 1918-00-9) (Table 1), was initially tested at concentrations of $0.781,7.81$ and $78.1 \mu \mathrm{g} \mathrm{mL}^{-1}$ based on the 80 recommended application concentration of two tablespoons per gallon $\left(=7.81 \mu \mathrm{L} \mathrm{mL}^{-1}\right)$. A subsequent trial tested concentrations of $7.81,15.6$ and $39.178 .1 \mu \mathrm{g} \mathrm{mL} \mathrm{L}^{-1}$ to increase resolution across the observed effective range. PAH test concentrations were based upon levels reported from Murrells Inlet, South Carolina, US (Fortner et al. 1997). Increases in PAH toxicity due to photoactivation following exposure to ultraviolet light (Lyons et al. 2002) was also examined.

85 Ultraviolet A and B light levels measured in streams and tributaries of coastal South Carolina, US indicated that $200 \mu \mathrm{Ws} \mathrm{cm} \mathrm{cm}^{-2}$ would provide a realistic exposure level for testing photoactivated toxicity (J. Weinstein, The Citadel, pers. comm.). Because acetone was used as a solvent for PAHs and also in the herbicide concentrate, its effect was tested at concentrations spanning those used in the treatments.

90 Each isolate was challenged in separate 24-well plates with only one chemical at a time to avoid cross-contamination among chemicals or isolates. All experiments were performed at $25^{\circ} \mathrm{C}$ and controls in fresh culture medium were run for each chemical tested. All treatments 
were prepared in triplicate $(3$ wells $x 3$ concentrations + three control wells $=12$ wells) for each isolate. One well from each isolate $(\mathrm{n}=3)$ was sacrificed a 2, 48 and $144 \mathrm{hr}$ to determine cell

95 proliferation via replicated hemocytometer counts (LaPeyre and Chu 1994). Counts were repeated until multiple counts were within about $10 \%$ of each other.

Two-way analysis of variance (ANOVA $\alpha=0.05$ ) indicated no interactions between time and chemical concentration for any treatments (Table 2), enabling the effects of time and concentration to be interpreted independently. Time was significant in all experiments as a result of cell proliferation, but only the herbicide Weed-B-Gon® showed a significant effect of concentration (Table 2). In trial 1, cells were killed within $2 \mathrm{hr}$ at $78.1 \mu \mathrm{g} \mathrm{mL}^{-1}$, but there was no difference from the control at 7.81 and $0.781 \mu \mathrm{g} \mathrm{mL}^{-1}$ (data not shown). The second trial indicated a dose response with reductions in proliferation at concentrations of 15.6 , and $39.2 \mu \mathrm{g}$ $\mathrm{mL}^{-1}$ that became more pronounced over time (Figure 1).

Shellfish that inhabit estuaries can be affected directly by contaminants through adsorption and ingestion or indirectly through the food web (Karlander et al. 1983, Croonenberghs 2002). In addition, shellfish might be indirectly affected when contaminants affect their parasites. Many anthropogenic chemical contaminants are introduced daily into 110 estuarine systems from point and non-point sources. Fertilizers, pesticides and herbicides enter estuaries in runoff from farmlands, golf courses, and residential areas (Knutzen 1987, Howarth et al. 2002). Polycyclic aromatic hydrocarbons (PAHs) are by-products of fossil fuel combustion that enter estuaries as runoff from roads and via atmospheric deposition (Knutzen 1987). The chemical contaminants used in the present study were selected because previous studies

115 documented their presence in estuarine waters of the southeastern United States (Vernberg et al. 
1997) were P. marinus commonly infects oysters (Bobo et al. 1996). Four of the contaminants are commonly used on golf courses, farms and residential lawns as fertilizers (ammonium, nitrate and phosphate) or herbicides (Weed-B-Gon $\left.{ }^{\circledR}\right)$. The active ingredients of Weed-B-Gon® (2,4-D, mecoprop and dicamba) are general broadleaf herbicides common to both industrial (e.g., agriculture, golf courses) and residential (lawn and garden) use (Burnside 1996). Concentrations of 2,4-D, mecoprop and dicamba in estuarine waters were not available, although they are listed among the anthropogenic chemicals found in southeastern US estuaries (Vernberg et al. 1997). The other two compounds (fluoranthene and phenanthrene) are polycyclic aromatic hydrocarbon (PAH) by-products of combustion engines.

The lack of effect by PAHs is noteworthy due to the effects that these chemicals can have on oysters. For example, PAHs are known to increase hemocyte activity, cause a thinning of the digestive epithelial tissue, disrupt larval development, and prevent embryos from entering the Dshell larval stage (Weinstein 1997, 2002, Oliver et al. 2001, Lyons et al. 2002). Some of these effects may decrease the oyster's ability to fight infection. Because oysters filter large volumes

130 of water and are known to concentrate contaminants, even relatively low concentrations of chemical contaminants may have significant effects on their health and vitality (Croonenberghs 2000). Moreover, by concentrating contaminants, parasites within the oysters might be exposed to higher contaminant concentrations than exist in the surrounding waters. Perkinsus marinus infection intensities and PAH distribution within estuaries have also been correlated suggesting

135 that either both have identical responses to environmental changes or there is a link between the two (Wilson et al. 1990, Wilson et al. 1992). Chu et al. (2002) demonstrated that oysters exposed to field contaminated sediments that contained several PAHs, metals and other organic compounds were more susceptible to $P$. marinus infection and/or intensification of extant 
infections. Results reported herein demonstrate that individual exposure to two common PAH

140 compounds, flouranthene and phenanthrene, at levels comparable to those used by Chu et al. (2002) did not affect in vitro proliferation of P. marinus.

The effects of increased nutrient loading are a concern in estuaries throughout the world. Nitrogen and phosphorus derived from various point and non-point sources have increased globally over the past 40 years by two to three times (Howarth 2002). The effects of nutrient

145 loading on $P$. marinus had not been previously examined, but results from this study suggest there is no direct effect. These nutrients encourage algal blooms, often leading to eutrophication that may increase abundance and biomass of benthic fauna like oysters (Nixon and Buckley 2002). In contrast, harmful algal blooms, which have also been linked to eutrophication, may produce toxins that kill or decrease the overall health and spawning of oysters (Pelley 1998,

150 Dortch et al. 1999).

Weed-B-Gon® significantly reduced proliferation of $P$. marinus, but only at concentrations greater than the recommended application rate. The herbicides contained in Weed-B-Gon® target broadleaf plants and mimic plant growth hormones or auxins. Both 2,4-D and mecoprop are phenoxy acid compounds whereas dicamba is a benzoic acid (PAN Pesticide

155 Database: www.pesticideinfo.org). In small doses they promote growth in broadleaf plants and research on its actions continues to reveal new insights (e.g., Hensel et al. 2002). At higher concentrations over stimulation interferes with fundamental processes eventually killing the plant (Munro et al. 1992). The effect on in vitro proliferation of $P$. marinus was also dose dependant, but stimulation at the lower dosages tested was not observed. Because $P$. marinus is not a plant, the mechanism of action is quite likely to be different. 
Several studies have examined the toxic effects of 2,4-D on cells from other organisms. For example, in human hepatoma cells, 2,4-D induced apoptosis by disrupting mitochondrial membrane potential in a dose dependent manner (Tuschl and Schwab 2003). Aria (2002) examined genotoxic effects of 2,4-D on developing chick embryos and found a dose dependent response of increasing sister chromatid exchange rates as well as an inhibition of the cell cycle. Mecoprop may have similar effects at high dosages while dicamba appears to be more benign (ECOTOXNET, http://extoxnet.orst.edu). Recently, Lund et al. (2005) found that the antimicrobial compound triclosan inhibited $P$. marinus proliferation but effective concentrations did not harm oyster hemocytes. Triclosan is chemically related to 2,4-D. As an antimicrobial, 170 triclosan interferes with fatty acid synthesis, but the concentration needed to affect $P$. marinus proliferation was less than half that needed to affect fatty acid synthesis of $P$. marinus. Working with $P$. olseni, a closely related molluscan pathogen, Elandalloussi et al. (2005) found that some antimalarial compounds designed to target folate synthesis inhibited P. olseni proliferation. These studies provide potential mechanisms to explain the dose response observed in the

175 herbicide treatment from the present study and warrant further investigation. Determining the mechanism(s) of action of the herbicide 2,4-D on P. marinus may identify metabolic pathways to target in the development of chemotherapeutants that may be useful under certain conditions (e.g., protecting valuable brood stock). The ability to target multiple pathways with different chemicals should help minimize the development of $P$. marinus populations resistant to any 180 particular treatment.

In the environment, parasites and their hosts are likely to be exposed to a suite of contaminants (e.g., Chu et al. 2002). Because the effect of each contaminant on the host and the parasite may differ and be further complicated by the interaction of various compounds, 
interpreting the effect of any single contaminant is specific to the entire suite of contaminants

185 present. In the current study, contaminant exposures were performed in vitro and most showed little effect. This is perhaps not surprising as the in vitro culture medium was designed to promote proliferation of $P$. marinus. Free-living stages or parasites within a host oyster are under conditions less likely to favor proliferation and may react differently to the contaminants employed here.

190

\section{ACKNOWLEDGEMENTS}

M Engle assisted in the laboratory and SE Ford provided helpful comments to the manuscript along with two anonymous reviewers. Financial support was provided by the Urbanization and Southeastern Estuarine Systems Project funded by NOAA through the South

195 Carolina Sea Grant Consortium. This paper represents contribution number 1450 of the Baruch Institute for Marine and Coastal Sciences.

\section{REFERENCES}

Anderson, R.S., Unger, M.A. \& Burreson, E.M. (1996). Enhancement of Perkinsus marinus disease progression in TBT-exposed oysters (Crassostrea virginica). Mar. Environ. Res. 42, $177-180$.

Anderson, R.S., Brubacher, L.L., Calvo, L.R., Unger, M.A. \& Burreson, E.M. (1998). Effects of tributyltin and hypoxia on the progression of Perkinsus marinus infections and host defense mechanisms in oyster, Crassostrea virginica (Gmelin). J. Fish Dis. 21(5), 371379. 
Aria, E. (2002). Sister chromatid exchange induction by the herbicide 2,4-

dichlorophenoxyacetic acid in chick embryos. Ecotox. Environ. Safety 55, 338-343.

Brown B.L., Butt A.J., Meritt D. \& Paynter K.T. (2005). Evaluation of resistance to Dermo in eastern oyster strains tested in Chesapeake Bay. Aquacult. Res. 36(15), 1544-1554.

210 Burnside, O. (1996). Biologic and economic assessment of benefits from use of phenoxy herbicides in the United States. Special NAPIAP report; no. 1-PA-96. National Agricultural Pesticide Impact Assessment Program, Washington, 227 p.

Burreson, E.M. \& Ragone Calvo, L.M. (1996). Epizootiology of Perkinsus marinus disease of eastern oysters in Chesapeake Bay, with emphasis on data since 1985. J. Shellfish Res. $15(1), 35-44$.

Bushek, D., Holley, R.A. \& Reece, K.S. (2000). Use of micromanipulation and "feeder" cultures to clone the protozoan oyster pathogen Perkinsus marinus. J. Eukaryotic Microbiol. 47(2), 164-166.

Chu, F-L.E. \& Hale, R.C. (1994). Relationship between pollution and susceptibility to infectious disease in the eastern oyster, Crassostrea virginica. Mar. Environ. Res. 38, $243-256$.

Chu, F-L.E., Volety, A.K., Hale, R.C. \& Huang, Y. (2002). Cellular responses and disease expression in oysters (Crassostrea virginica) exposed to suspended field-contaminated sediments. Mar. Environ. Res. 53, 17-35.

225 Croonenberghs, R.E. (2000). Contamination in shellfish-growing areas. In: Martin, R.E. et al. (eds.) Marine and freshwater products handbook (pp. 665-693). Lancaster: Technomic Publishing Co. 
Dortch, Q., Parsons, M.L., Rabalais, N.N. \& Turner, R.E. (1999). What is the threat of Harmful Algal Blooms in Louisiana coastal waters? In: Rozas et al. (eds) Recent Research in Coastal Louisiana: Natural System Function and Response to Human Influences (pp. 134-144). Lafayette: Louisiana Sea Grant College Program.

Elandalloussi, L.M., Rodrigues P.M., Afonso R., Leite R.B., Nunes P.A. \& Cancela, M.L. (2005). Shikimate and folate pathways in the protozoan parasite, Perkinsus olseni. Mol. Biochem. Parasitol. 142(1), 106-109.

235 Fisher, W.S., Oliver, L.M., Sutton, E.B., Walker, W.W., Manning, C.S. \& Lytle, T.F. (1999). Decreased resistance of eastern oysters (Crassostrea virginica) to a protozoan pathogen (Perkinsus marinus) after sublethal exposure to tributyltin oxide. Mar. Environ. Res. 47, 185-201.

Ford, S.E. \& Tripp, M.R. (1996). Diseases and defense mechanisms. In: Kennedy, V.S. et al. (eds), The Eastern Oyster, Crassostrea virginica (pp. 581-660). Baltimore: Maryland Sea Grant.

Fortner, A.R., Sanders, M. \& Lemire, S.W. (1997). Polynuclear aromatic hydrocarbon and trace metal burdens in sediment and the oyster, Crassostrea virginica Gmelin, from two highsalinity estuaries in South Carolina. In: Vernberg, F.J. et al. (eds), Sustainable Development in the Southeastern Coastal Zone (pp. 445-475). Columbia: University of South Carolina Press.

Gauthier, J.D. \& Vasta, G.R. (1995). In-vitro culture of the Eastern oyster parasite Perkinsus marinus - optimization of the methodology. J. Invert. Pathol. 66(2), 156-168. 
Heitkamp, M.A. Freeman, J.P. Miller, D.W. \& Cerniglia, C.E. (1988). Pyrene degradation by a Mycobacterium sp.: identification of ring oxidation and ring fission products. Appl. Environ. Microbiol. 54(10), 2556-2565.

Hensel, G., Kunze, G. \& Kunze, I. (2002). The influence of 2,4-dichlorophenoxyacetic acid on localization of the PR-proteins CBP20 and class I chitinase in tobacco suspension cells cultures. Plant Science 163, 1099-1106.

255 Howarth, R.W., Sharpley, A. \& Walker, D. (2002). Sources of nutrient pollution to coastal waters in the United States: implications for achieving coastal water quality goals. Estuaries 25(4B), 656-676.

Karlander, E.P., Mayasich, J.M. \& Terlizzi, D.E. (1983). Effects of the herbicide atrazine on an oyster-food organism. Maryland Water Resources Research Center Publication no. 73, p. 3 .

Knutzen, J. (1987). Sources, occurrence and effects of polycyclic aromatic hydrocarbons (PAH) in the aquatic environment -- a preliminary review. The National Technical Information Service. NIVA-E-87700/I, $21 \mathrm{pp}$.

Lafferty, K.D. (1997). Environmental parasitology: What can parasites tell us about human impacts on the environment? Parasitol. Today 13, 251-255.

LaPeyre, J.F. \& Chu, F-L.E. (1994). A simple procedure for the isolation of Perkinsus marinus merozoites, a pathogen of the Eastern oyster, Crassostrea virginica. Bull. Eur. Ass. Fish Pathol. 14(3), 101-103.

Lund, E.D., Soudant, P., Chu, F-L.E., Harvey, E., Bolton, S. \& Flowers, A. (2005). Effects of triclosan on growth, viability and fatty acid synthesis of the oyster protozoan parasite Perkinsus marinus. Dis. Aquatic Org. 67(3), 217-224. 
Lyons, B.P., Pascoe, C.K. \& McFadzen, I.R.B. (2002). Phototoxicity of pyrene and benzo[a]pyrene to embryo-larval stages of the pacific oyster Crassostrea gigas. Mar. Environ. Res. 54, 627-631.

275 Munro, I.C., Carlo, G.L., Orr, J.C., Sund, K.G., Wilson, R.M., Kennepohl, E., Lynch, B.S., Jablinske, M, \& Lee, N.L. (1992). A Comprehensive, Integrated Review and Evaluation of the Scientific Evidence Relating to the Safety of the Herbicide 2,4-D. J. Am. Col. Toxicol. 11(5), 559-664.

Nixon, S.W. \& Buckley, B.A. (2002). A strikingly rich zone- nutrient enrichment and secondary production in coastal marine ecosystems. Estuaries 25(4B), 782-796.

Oliver, L.M., Fisher, W.S., Winstead, J.T., Hemmer, B.L. \& Long, E.R. (2001). Relationships between tissue contaminants and defense-related characteristics of oysters (Crassostrea virginica) from five Florida bays. Aquat. Toxicol. 55, 203-222.

Pelley, J. (1998). What is causing toxic algal blooms? Environ. Science Technol. 32(1), 26A$30 \mathrm{~A}$

Reece, K.S., Bushek, D., Hudson, K.L. \& Graves, J.E. (2001). Geographic distribution of Perkinsus marinus genetic strains along the Atlantic and Gulf coasts of the USA. Mar. Biol. 139, 1047-1055.

Rothschild, B.J., Ault, J.S., Goulletquer, P \& Heral, M. (1994). Decline of the Chesapeake Bay oyster population: A century of habitat destruction and over fishing. Mar. Ecol. Prog. Ser. 11(1-2), 29-39.

Tuschl, H. \& Schwab, C. (2003). Cytotoxic effects of the herbicide 2,4-dichlorophenoxyacetic acid in HepG2 cells. Food Chemical Toxicol. 4, 385-393. 
Vernberg, F.J., Vernberg, W.B. \& Siewicki, T. (1997). Sustainable Development in the Southeastern Coastal Zone. Belle W. Baruch Library in Marine Science, Vol. 20, (535 pp.). Columbia: University of South Carolina Press.

Weinstein, J.E. (2002). Photoperiod effects on the UV-induced toxicity of fluoranthene to freshwater mussel glochidia: absence of repair during dark periods. Aquat. Toxicol. 59, $153-161$.

300 Weinstein, J.E. (1997). Flouranthene-induced histological alterations in oysters, Crassostrea virginica: Seasonal field and laboratory studies. Mar. Environ. Res. 43(3), 201-218.

Wilson, E.A., Powell, E.N., Craig, M.A., Wade, T.L. \& Brooks, J.M. (1990). The distribution of Perkinsus marinus in the Gulf Coast oyster: its relationship with temperature, reproduction, and pollutant body burden. Int. Rev. ges. Hydrobiologica 75(4), 533-550.

305 Wilson, E.A., Powell, E.N., Wade, T.L., Taylor, R.J., Presley, B.J. \& Brooks, J.M. (1992).

Spatial and temporal distributions of contaminant body burden and disease in Gulf of Mexico oyster populations: The role of local and large-scale climatic controls. Helgoländer Meeresuntersuchungen 46, 201-235. 
310 Table 1. Chemicals and concentrations tested.

$\underline{\text { Compound }} \quad \underline{\text { Chemical formula }}$ Concentrations tested

Weed-B-Gon ${ }^{\circledR}$

$0.781,7.81,15.6,39.2$ and $78.1 \mu \mathrm{L} \mathrm{mL}^{-1}$

$$
\begin{array}{ll}
\text { 2,4-D (3.05\%) } & \mathrm{C}_{10} \mathrm{H}_{13} \mathrm{Cl}_{2} \mathrm{NO}_{3} \\
\text { Mecoprop (10.6\%) } & \mathrm{C}_{12} \mathrm{H}_{18} \mathrm{ClNO}_{3}
\end{array}
$$

$315 \quad$ Dicamba (1.3\%) $\quad \mathrm{C}_{8} \mathrm{H}_{6} \mathrm{Cl}_{2} \mathrm{O}_{3}$

Ammonium

Nitrate

Phosphate

Fluoranthene

320
Phenanthrene

Acetone
$\mathrm{NH}_{4}$

$\mathrm{NO}_{3}$

$\mathrm{PO}_{4}$

$\mathrm{C}_{20} \mathrm{H}_{12}$

$\mathrm{C}_{14} \mathrm{H}_{10}$

$\mathrm{C}_{3} \mathrm{H}_{6} \mathrm{O}$
$0.18,1.8$ and $18 \mu \mathrm{M}$

$0.036,0.36$, and $3.6 \mu \mathrm{M}$

$0.0055,0.055,0.09$ and $0.9 \mu \mathrm{M}$

$0.236,2.36$, and $23.6 \mu \mathrm{g} / \mathrm{L}$

$0.45,2.3$ and $4.5 \mu \mathrm{g} / \mathrm{L}$

$0.1,1.0$ and $10 \% \mathrm{v} / \mathrm{v}$ 
Table 2. Probability values from two factor ANOVAs of chemical challenge experiments.

Headings represent sources of variation. Significant values are in bold.

325

\begin{tabular}{|c|c|c|c|c|}
\hline & Chemical & $\mathrm{e}^{*}$ Treatment & $\underline{\text { Time }}$ & Concentration \\
\hline & Ammonium & 0.999 & 0.000 & 0.906 \\
\hline & Nitrate & 0.999 & 0.000 & 0.845 \\
\hline & Phosphate & 0.999 & 0.000 & 1.000 \\
\hline 330 & Weed-B-Gon ${ }^{\circledR}($ trial 1) & 0.406 & 0.003 & 0.006 \\
\hline & Weed-B-Gon ${ }^{\circledR}($ trial 2$)$ & 0.353 & 0.000 & 0.009 \\
\hline & Fluoranthene & 0.995 & 0.000 & 0.852 \\
\hline & Fluoranthene UV-activated & 0.552 & 0.000 & 0.128 \\
\hline & Phenanthrene & 1.000 & 0.064 & 0.978 \\
\hline 335 & Phenanthrene UV-activated & 0.943 & 0.000 & 0.409 \\
\hline & Acetone & 0.814 & 0.000 & 0.829 \\
\hline
\end{tabular}


Figure 1. Effect of Weed-B-Gon ${ }^{\circledR}$ herbicide on in vitro proliferation of $P$. marinus. Data are means with standard errors of the three replicate parasite strains. 


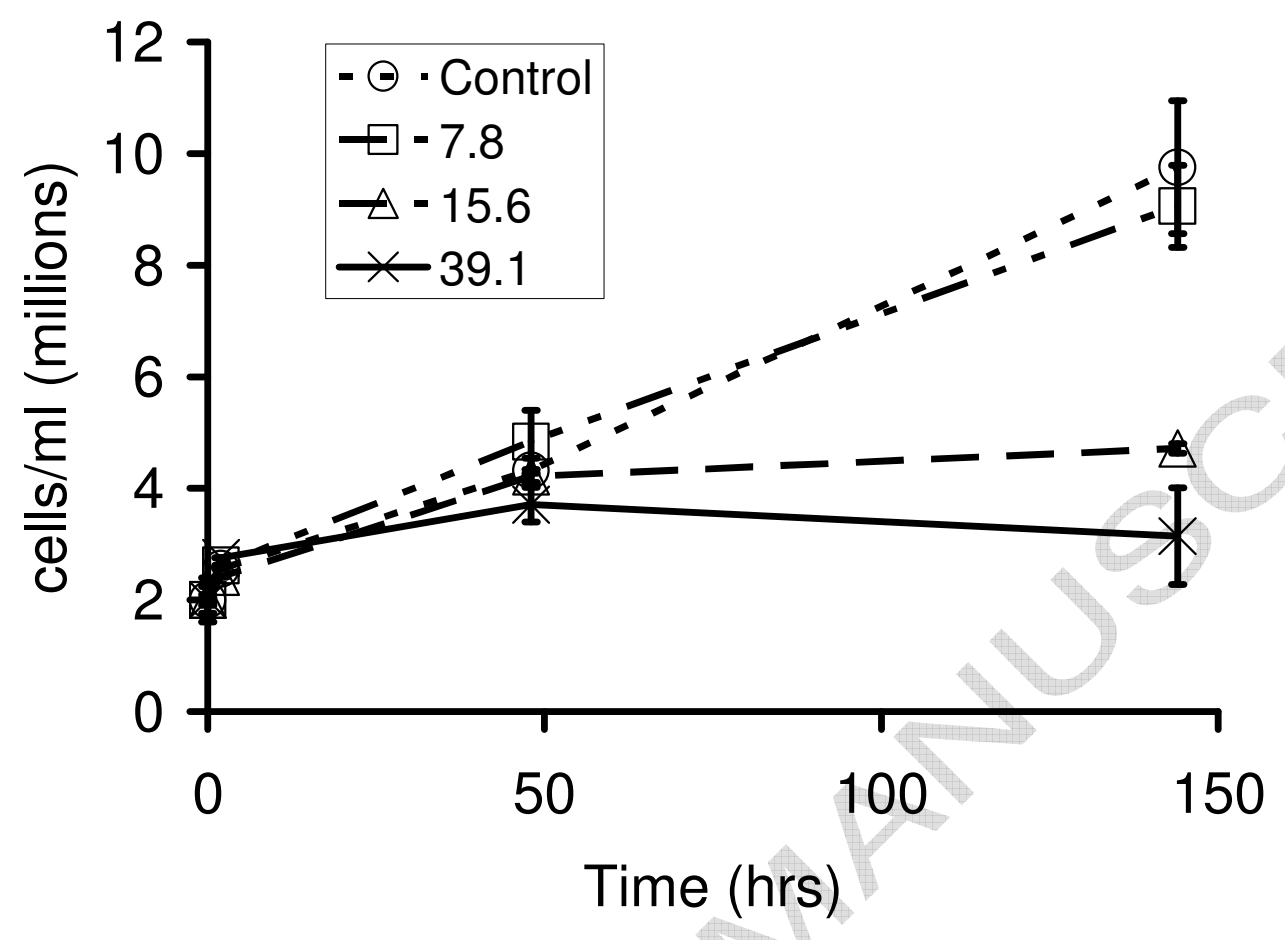

